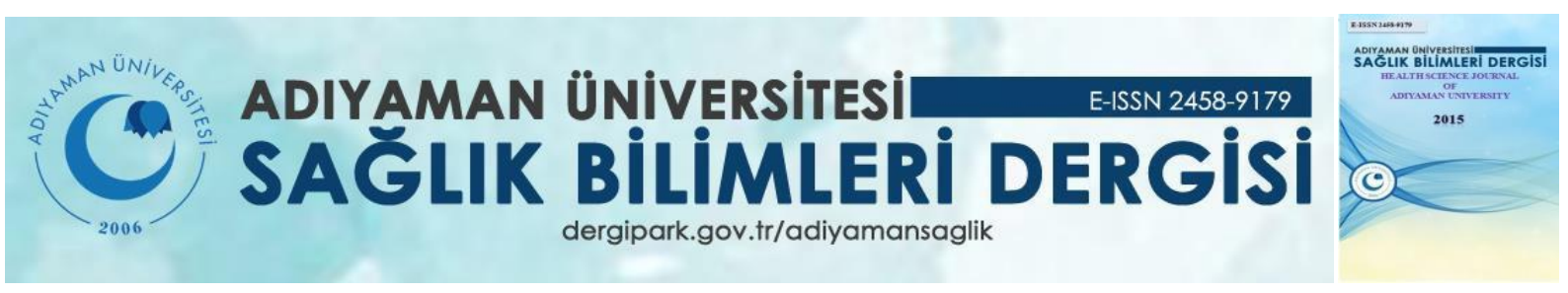

Araştırma/Research

\title{
Hemşirelik Birinci Sınıf Öğrencilerinin İlk Klinik Uygulamaya Başlamadan Önce Ve Sonrasında Anksiyete Ve Uyku Yönünden Karşılaştırılması
}

\section{Aliye BULUT ${ }^{1}$, Gülay ÇELİK ${ }^{2}$}

${ }^{1,2}$ Bingöl Üniversitesi, Sağlık Bilimleri Fakültesi, Hemşirelik Bölümü, Bingöl/ Türkiye

${ }^{1}$ ORCID: 0000-0002-4326-0000 / ${ }^{2}$ ORCID: 0000-0003-1504-6792

\section{ÖZ}

Amaç: Bu çalışma, Bingöl Üniversitesi Sağlık Bilimleri Fakültesi Hemşirelik Bölümü birinci sınıf öğrencilerinin ilk klinik uygulamaya başlamadan önce ve başladıktan sonra anksiyete düzeyleri ve uyku kalitelerini saptamak amacıyla tanımlayıcı olarak yapılmıştır.

Gereç ve Yöntem: Araştırmanın evrenini, 2018-2019 Akademik yılında Sağlık Bilimleri Fakültesi Hemşirelik Bölümü birinci sınıfta öğrenimini sürdüren 74 öğrenci oluştururken, örneklemini ise, katılmayı kabul eden 60 öğrenci oluşturmuştur. Araştırma verileri, 15 Nisan - 15 Mayıs 2019 tarihleri arasında toplanmıştır. Araştırma verilerinin toplanmasında, "Anket Formu”, "Pittsburgh Uyku Kalite İndeksi" ve "Beck Anksiyete Ölçeği”" kullanılmıştır.

Bulgular: Çalışmaya 36 kadın, 24 erkek olmak üzere 60 hemşirelik öğrencisi katılmıştır. Çalışmaya katılanların çoğunluğu (\%66.7) il merkezinde yaşadığını ifade etmiştir. Anne ve babalarının eğitim durumunun en fazla ilköğretim (sırasıyla \%46.7, \%45.0) olduğu belirlenmiştir. Öğrencilerin \%66.7'si hemşirelik bölümünü isteyerek seçtiğini ifade etmiştir. PUKİ puanlarına göre klinik uygulama öncesi uyku kalitesi iyi olan öğrencilerde klinik uygulama sonrası düşüş görülmüştür. Öğrencilerin klinik uygulama sonrası anksiyete düzeylerinde klinik uygulama öncesine göre artış görülmekle birlikte aralarındaki fark anlamlı bulunmamıştır ( $\mathrm{p}>0.05)$.

Sonuç: PUKİ puanlarına göre klinik uygulama öncesi uyku kalitesi iyi olan öğrencilerde klinik uygulama sonrası düşüş görülmüştür. Erkek öğrencilerin ve hemşirelik bölümünü isteyerek seçen öğrencilerin klinik uygulama sonrası anksiyete düzeyleri klinik uygulama öncesi anksiyete düzeylerine göre daha yüksek bulunmuştur $(\mathrm{p}<0.05)$. Uyku kalitesi ve anksiyete düzeyleri ile öğrencilerin klinik uygulamaya çıkma durumlarının ilişkisini inceleyen araştırmaların yapılması önerilmektedir.

Anahtar Kelimeler: Hemşirelik öğrencileri, Uyku, Anksiyete

Yazışmadan Sorumlu Yazar:

Dr.Öğretim Üyesi Aliye BULUT

Adres: Bingöl Üniversitesi, Sağlık Bilimleri Fakültesi

Hemşirelik Bölümü 12000 Bingöl/ Türkiye

Telefon: +90 (0505) 8173113

e-mail: aliyedemirok@yahoo.com

ORCID: 0000-0002-4326-0000

Doi: 10.30569.adiyamansaglik.630050

Geliş Tarihi : 07.10.2019

Kabul Tarihi : 08.11.2019

Atıf Gösterimi/How to Cite: Bulut A, Çelik. Hemşirelik Birinci Sınıf Öğrencilerinin İlk Klinik Uygulamaya Başlamadan Önce Ve Sonrasında Anksiyete Ve Uyku Yönünden Karşılaştırılması. Adıyaman Üni. Sağlık Bilimleri Derg. 2019; 5(3);1675-1687. doi:10.30569.adiyamansaglik.630050 


\section{Comparison of Nursing First Class Students in terms of Anxiety and Sleep Before and After the First Clinical Practice}

\section{ABSTRACT}

Objective: This study was conducted as a descriptive study in order to determine the anxiety levels and sleep quality of the first year students of Bingöl University Faculty of Health Sciences, Department of Nursing.

Matarial and Method: The population of the study consisted of 74 students who were in their first year of education Faculty of Health Sciences in 2018-2019 Academic year, while the sample consisted of 60 students who volunteered to participate in the study. The research data were collected between 15 April and 15 May 2019. "Survey Form”, “'Pittsburgh Sleep Quality Index" and "Beck Anxiety Scale" were used to collect the data.

Results: 36 female and 24 male and 60 nursing students participated in the study. The majority of the participants $(66.7 \%)$ stated that they lived in the city center. It was determined that the education level of the parents was mostly primary education $(46.7 \%, 45.0 \%$ respectively). $66.7 \%$ of the students stated that they chose the nursing department willingly. According to PSQI scores, students with good sleep quality before internship decreased after internship. Anxiety levels of the students increased after the internship compared to the pre-internship, but the difference was not significant ( $p>0.05)$.

Conclusion: According to PSQI scores, students with good sleep quality before internship decreased after internship. After the internship anxiety levels of the male students and the students who willingly chose nursing department were found to be higher than the preinternship anxiety levels ( $\mathrm{p}<0.05$ ). It is recommended to conduct research on the relationship between sleep quality and anxiety levels and the internship status of the students.

Keywords: Nursing students, Sleep, Anxiety 


\section{GİRis}

Anksiyete zihinsel, bedensel, emosyonel ve davranışsal faktörleri olan fizyolojik bir durumdur. $\mathrm{Bu}$ faktörler bir araya geldiğinde bireyde, huzursuzluk, kaygı, korku gibi hoş olmayan bir duruma sebep olur (1).

Fizyolojik anksiyetenin bireyi koruyan ve motive eden bir özelliği vardır. Bireyin stresle başa çıkabilmesi için anksiyetenin olumlu bir etkisi bulunmaktadır. Anksiyete; uyaranın şiddeti ile orantısız olması, zamanla azalacağı beklenirken değişmemesi ya da artması, klinik tabloya bakıldığında fiziksel belirtilerinin ağırlıkta olması ve fonksiyonelliğin bozulması gibi durumlarda patolojik olarak değerlendirilir (2). Anksiyete patolojik boyuta ulaşmış ise, kişinin sosyal ve özel hayatını olumsuz etkilemeye başlar ve kişi bunu kontrol edemez, bu durumla baş edemez hale gelir. Bu belirtilerin yanı sıra birey; öfke, huzursuzluk, sinirlilik, daralma, çabuk yorulma, konsantrasyon güçlüğü, uykusuzluk semptomları yaşayabilir. Anksiyetede görülebilecek psikolojik değişiklikler arasında baş ağrısı, baş dönmesi, ağlama nöbetleri, ağızda kuruluk, çarpıntı, nefes almada zorluk, vücudun çeşitli yerlerinde ağrı, kaslarda güçsüzlük, bitkinlik ve gastrointestinal yakınmaların yer aldığı söylenebilir $(1,2)$.

Uyku ise; bilincin algılama ve dış uyaranlara uygun cevaplar verebilme yetisinin, dış uyaranların bir kısmının veya tamamının algılanamadığı, verilen tepkinin zayıfladığı ve vücuttaki pek çok organın fonksiyonunun büyük oranda azaldığı, organlardan oluşan sistemlerin yavaşladığı dinlenme durumudur. Ancak uyku sırasında beyinin tam bir dinlenme durumunda bulunmadığı, uykuda çalıştığı, etkinlik durumunun değiştiği düşünülmektedir. Bunun kaynağı olarak da uyku sırasında beyinde elektriksel olayların sürdüğü ve çeşitli elektroensefalogram (EEG) dalgalarının kaydedilmesidir (3). Uyku bozuklukları sık görülen sağlık sorunlarındandır $(3,4)$. Çalışmalar uyku ile ilgili sağlık sorunlarının sıklığının değerlendirilmesi sonucunda, bu sorunun bir halk sağlı̆̆ı sorunu olarak değerlendirilebileceğini göstermektedir (4).

Hemşirelik eğitimi ve klinik uygulamaları, sadece bilgiyi değil bununla beraber mesleki tecrübe edinmeyi de amaçlamaktadır (5). Klinik tecrübe ve uygulama hemşirelik öğrencilerinin eğitimi açısından en çok anksiyete oluşturan durumlardan birisidir (6).

Klinik öğrenme, öğrencilerde anksiyeteye neden olan önemli bir faktördür (6). Özellikle ilk klinik deneyim ve bu deneyimde yaşananlar tahmin edilemez ve öğrenciyi zorlayıcı olmasından dolayı daha çok anksiyete oluşturabilmekte (7), dolayısıyla uyku kalitesini de olumsuz etkileyebilmektedir. 
Öğrenciler, ilk klinik uygulamaya başlarken hata yapıp hastayı zarara uğratma, olumsuz durumlarla karşılaşma gibi düşünceler ve bunlara bağl1 özgüven eksikliği sebebiyle yoğun anksiyete yaşamaktadır. Öğrenci, anksiyeteyle başa çıkmaya çalışırken, sağlık personeli ile ilişki kurmada güçlük, sorunlarla baş etme yetisinde ve sosyal ilişkilerde zorluk da yaşar $(8,9)$. Bu nedenle öğrencilerin klinik uygulamanın her bir aşamasında anksiyete ve uyku kalitelerinin araştırılması ve bu durumu etkileyen faktörlerin incelenmesi önem taşımaktadır. Literatüre göre, bu konuda yapılan çalışmalarda öğrencilerin ilk klinik uygulamalarında yaşadıkları anksiyete, stres ya da kaygı düzeyleri incelenmiştir (7,10-12). Öğrencilerin ilk klinik uygulamalarına ilişkin anksiyete ve uyku kalitesi düzeylerini beraber araştıran bir çalışma bulunmamaktadir.

$\mathrm{Bu}$ çalışma, hemşirelik birinci sınıfta eğitim görmekte olan öğrencilerin klinik uygulama öncesi ve sonrası anksiyete ve uyku kalitesi düzeylerini ve bunlara etki eden faktörleri belirlemek amacıyla yapılmıştır.

\section{GEREÇ VE YÖNTEM}

\section{Katılimcilar}

Tanımlayıcı tipteki bu araştırma, Bingöl Üniversitesi Sağlık Bilimleri Fakültesi Hemşirelik Bölümü birinci sınıfta bulunan öğrencilerin ilk klinik uygulamaya başlamadan önce ve klinik uygulamaya başladıktan 2 ay sonra anksiyete düzeyleri ve uyku kalitelerini belirlemek amaciyla yapılmıştır. Araştırmanın evrenini, 2018-2019 Akademik yılında Bingöl Üniversitesi Sağlık Bilimleri Fakültesi Hemşirelik Bölümü birinci sınıfta öğrenimlerini sürdüren 74 öğrenci oluştururken; örneklemini ise, araştırmaya katılmayı kabul eden 60 öğrenci oluşturmuştur. Araştırma Helsinki İlkeleri Deklerasyonu'na uygun olarak hazırlanmış ve yapılabilmesi için ilgili üniversitenin Bilimsel Araştırma ve Yayın Etik Kurulundan yazılı izin (2018/51 sayı ve 10/12/2018 tarihli) alınmıştır. Ayrıca, anket uygulanmadan önce katılımcılardan sözel izin alınmıştır.

\section{Verilerin Toplanmast}

Literatür kaynaklı olarak araştırıcılar tarafindan oluşturulan anket formu üç bölümdür. Formun birinci bölümü sosyo-demografik özellikleri sorgulayan 16 adet tanımlayıcı soru takımından, ikinci bölümü, "Pittsburgh Uyku Kalite İndeksi”nden, üçüncü bölüm ise, "Beck Anksiyete Ölçeği” nden oluşmuştur. 


\section{Pittsburgh Uyku Kalite İndeksi (PUKi)}

Pittsburgh Uyku Kalite İndeksi (PUKİ), 1989 yılında Buyse ve arkadaşları tarafından geliştirilmiş ve ölçeğin Türkiye'deki geçerlik ve güvenirlik çalışması Ağargün ve arkadaşları tarafından yapılmıştır (13). Uyku kalitesini saptayan ölçek 18 özbildirim sorusundan oluşmaktadır ve son 4 haftadaki uyku kalitesini değerlendirmektedir. PUKİ' nin 7 bileşeni vardır ve her bir bileşen 0-3 puan arasında değerlendirilmektedir. Toplam puan 0-21 arasında değişmektedir (14). Toplam puanın 5'ten yüksek olması uyku kalitesinin kötü olduğunu göstermektedir (15). PUKİ' nin bileşenleri; öznel uyku kalitesi, uyku latensi, uyku süresi, alışılmış uyku etkinliği, uyku bozukluğu, uyku ilacı kullanımı, gündüz işlev bozukluğu olarak sıralanmaktadır. Türkçe uyarlaması için Cronbach alfa iç tutarlılık katsayısı 0.80 olarak saptanmıştır (14). Çalışmamızda ise Cronbach's alpha değeri 0,73 olarak bulunmuştur.

\section{Beck Anksiyete Ölçĕ̆i}

Beck Anksiyete Ölçeği, anksiyete düzeyini ölçmek için 1988'de Beck ve arkadaşları tarafından geliştirilen kendini değerlendirme ölçeği olup, 21 maddelik likert tiptedir. Bireyden semptomları 'bugün dahil son bir hafta' içinde olacak şekilde değerlendirmesi istenir. Semptomlar hiç yok, hafif düzeyde var, orta düzeyde, ciddi düzeyde var şeklinde değerlendirilmektedir. Ölçeğin Türkçe geçerlilik ve güvenilirliği Ulusoy ve arkadaşları (1998) tarafından yapılmıştır. Beck Anksiyete Ölçeği'ne göre toplam puan 0-63 arası değişmekle birlikte, 0-7 puan minimum düzeyde anksiyete belirtileri, 8- 15 puan hafif düzeyde, 16-25 puan orta derece anksiyete ve 26-63 puan şiddetli anksiyete semptomları şeklinde sınıflandırılmaktadır. Türkçe uyarlaması için Cronbach's alpha iç tutarlık katsayısı 0,93'tür (16). Çalışmamızda ise Cronbach's alpha değeri 0,60 olarak bulunmuştur.

\section{Verilerin Analizi}

Araştırmadan elde edilen bulgular, Statistical Programme for Social Sciences (SPSS) for Windows 22 programı ile değerlendirilmiştir. Verilerin analizinde tanımlayıcı istatistikler; sayı, yüzde, minimum ve maksimum değerler, ortalama ve standart sapma şeklinde verilmiştir. Aynı bireylerde farklı iki zamanda tekrarlanan ölçümlerden elde edilen 'iyi-kötü' şeklinde iki kategorili farkı test etmek için, bağımlı iki örneklem testi olan Mc Nemar Testi kullanılmıştır. Aynı bireylerde farklı iki zamanda tekrarlanan ölçümlerden elde edilen 'hafif-orta-şiddetli' şeklinde üç kategorili farkı test etmek için ise, bağımlı iki örneklem testi olan Mc Nemar Bowker Testi kullanılmıştır. Anlamlılık p<0,05 olarak kabul edilmiştir. 


\section{BULGULAR}

Tablo 1. Katılımcıların bazı özelliklerine göre dağılımı $(\mathrm{N}=60)$

\begin{tabular}{|c|c|c|}
\hline Özellikler & Sayı & $\%$ \\
\hline $\begin{array}{l}\text { Yaş } 19.13 \pm 1.09 \text { min.-max.(18-22) } \\
20 \text { ve alt1 } \\
21 \text { ve üstü }\end{array}$ & $\begin{array}{c}54 \\
6\end{array}$ & $\begin{array}{l}90 \\
10\end{array}$ \\
\hline $\begin{array}{l}\text { Cinsiyet } \\
\text { Kadın } \\
\text { Erkek }\end{array}$ & $\begin{array}{l}36 \\
24\end{array}$ & $\begin{array}{l}60 \\
40\end{array}$ \\
\hline $\begin{array}{l}\text { Aile tipi } \\
\text { Çekirdek } \\
\text { Geniş }\end{array}$ & $\begin{array}{c}52 \\
8\end{array}$ & $\begin{array}{l}86.7 \\
13.3\end{array}$ \\
\hline $\begin{array}{l}\text { Hayatının çoğunun geçtiği yer } \\
\text { Kırsal bölge } \\
\text { Kentsel bölge }\end{array}$ & $\begin{array}{l}20 \\
40\end{array}$ & $\begin{array}{l}33.3 \\
66.7\end{array}$ \\
\hline $\begin{array}{l}\text { Annenin eğitim düzeyi } \\
\text { Okuryazar } \\
\text { İlköğretim mezunu } \\
\text { Ortaöğretim mezunu } \\
\text { Üniversite ve üstü mezunu }\end{array}$ & $\begin{array}{c}25 \\
28 \\
5 \\
2\end{array}$ & $\begin{array}{l}41.7 \\
46.7 \\
8.4 \\
3.3\end{array}$ \\
\hline $\begin{array}{l}\text { Babanın eğitim düzeyi } \\
\text { Okuryazar değil } \\
\text { İlköğretim mezunu } \\
\text { Ortaöğretim mezunu } \\
\text { Üniversite ve üstü mezunu }\end{array}$ & $\begin{array}{c}11 \\
27 \\
18 \\
4\end{array}$ & $\begin{array}{c}18.3 \\
45.0 \\
30.0 \\
6.7\end{array}$ \\
\hline $\begin{array}{l}\text { Gelir durumu } \\
\text { Gelirim fazla } \\
\text { Gelir giderim eşit } \\
\text { Giderim fazla } \\
\end{array}$ & $\begin{array}{c}6 \\
21 \\
33\end{array}$ & $\begin{array}{l}10 \\
35 \\
55\end{array}$ \\
\hline $\begin{array}{l}\text { Çalışma durumu } \\
\text { Evet } \\
\text { Hayır }\end{array}$ & $\begin{array}{c}2 \\
58\end{array}$ & $\begin{array}{c}3.3 \\
96.7\end{array}$ \\
\hline $\begin{array}{l}\text { Sigara kullanma durumu } \\
\text { Evet } \\
\text { Hayır }\end{array}$ & $\begin{array}{c}9 \\
51\end{array}$ & $\begin{array}{l}15 \\
85\end{array}$ \\
\hline $\begin{array}{l}\text { Herhangi bir kronik hastalık } \\
\text { Var } \\
\text { Yok }\end{array}$ & $\begin{array}{c}4 \\
56\end{array}$ & $\begin{array}{c}93.3 \\
6.7\end{array}$ \\
\hline $\begin{array}{l}\text { Hemşirelik bölümünü isteyerek seçme durumu } \\
\text { Evet } \\
\text { Hayır }\end{array}$ & $\begin{array}{l}40 \\
20\end{array}$ & $\begin{array}{l}66.7 \\
33.3\end{array}$ \\
\hline
\end{tabular}

Katılımcıların yaş ortalaması 19,13 (min-max:18-22, SS:1,09) olarak bulunmuştur. Katılımcıların \%60’ı kadın, \%40’ı ise erkektir. Çalışmaya katılanların çoğunluğu (\%66.7) il merkezinde yaşadığını ifade etmiştir. Anne ve babalarının eğitim durumunun en fazla ilköğretim (sırasıyla \%46.7, \%45.0) olduğu belirlenmiştir. Çalışmaya katılan öğrencilerin \%55'inin gelir durumunun düşük düzeyde olduğu belirlenmiştir. Öğrencilerin \%66.7'si hemşirelik bölümünü isteyerek seçtiğini ifade etmiştir (Tablo 1). 
Tablo 2. Katılımcıların Pittsburgh Uyku Kalite İndeksi (PUKİ) değerlerinin klinik uygulama öncesi ve klinik uygulama sonrası dağ̊lımı

\begin{tabular}{|l|cc|cc|c|}
\hline & \multicolumn{2}{|c|}{$\begin{array}{c}\text { Klinik uygulama } \\
\text { öncesi }\end{array}$} & \multicolumn{2}{c|}{ Klinik uygulama } & \multirow{2}{*}{ Analiz } \\
\hline PUKİ değeri & Sayı & \% & Sayı & \% & \\
\hline İyi (0-4 puan) & 14 & 23.3 & 7 & 11.7 & \\
Kötü (5 ve üzeri puan) & 46 & 76.7 & 53 & 88.3 & \multirow{2}{*}{$\mathrm{p}=0.143$} \\
Toplam & 60 & 100 & 60 & 100 & \\
\hline
\end{tabular}

*Aynı bireylerde farklı iki zamanda tekrarlanan ölçümlerden elde edilen 'iyi-kötü’ şeklinde iki kategorili fark1 test etmek için, bağımlı iki örneklem testi olan Mc Nemar Testi kullanılmıştır.

Klinik uygulama öncesi 14 öğrencinin uyku kalitesi iyi iken, klinik uygulama sonrası sadece 7 öğrencinin uyku kalitesi iyi olarak bulunmuştur (Tablo 2).

Tablo 3. Katılımcıların bazı değişkenlere göre klinik uygulama öncesi ve klinik uygulama sonrası Pittsburgh Uyku Kalite İndeksi değerlerinin karşılaştırılması

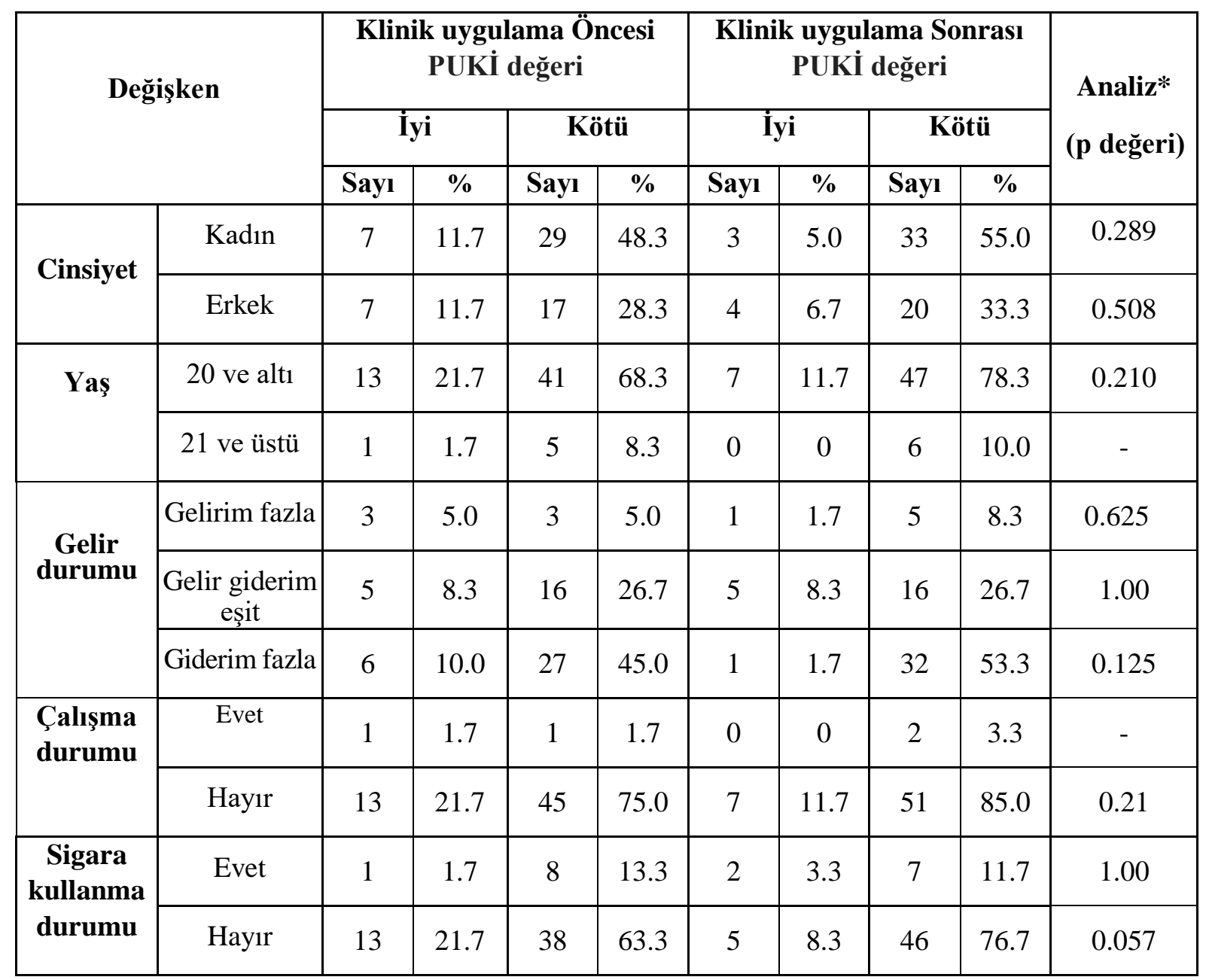




\begin{tabular}{|c|c|c|c|c|c|c|c|c|c|c|}
\hline $\begin{array}{c}\text { Hemşirelik } \\
\text { Bölümünü } \\
\text { isteyerek } \\
\text { seçme } \\
\text { durumu }\end{array}$ & Evet & 9 & 15.0 & 31 & 51.7 & 4 & 6.7 & 36 & 60.0 & 0.227 \\
\cline { 2 - 9 } & Hayır & 5 & 8.3 & 15 & 25.0 & 3 & 5.0 & 17 & 28.3 & 0.687 \\
\hline
\end{tabular}

*Aynı bireylerde farklı iki zamanda tekrarlanan ölçümlerden elde edilen 'iyi-kötü' şeklinde iki kategorili farkı test etmek için, bağımlı iki örneklem testi olan Mc Nemar Testi kullanılmıştır.

Araştırmada yer alan öğrencilerin uyku kalitesine göre PUKİ değerleri klinik uygulama öncesi ve klinik uygulama sonrası olacak şekilde karşılaştırılmıştır. Uyku kalitesi iyi ve kötü olanların yaş, cinsiyet, gelir durumu, çalışma, sigara kullanma ve bölümü isteyerek seçme durumlarına göre PUKİ değerleri klinik uygulama önce ve sonrası olarak karşılaştırıldığında aralarında istatistiksel açıdan anlamlı fark bulunmamıştır (Tablo 3;p>0.05).

Tablo 4. Katılımcıların Beck Anksiyete Ölçeği'nden aldıkları puanlara göre klinik uygulama öncesi ve klinik uygulama sonrası anksiyete düzeylerinin dağılımı

\begin{tabular}{|c|c|c|c|c|c|}
\hline & \multicolumn{2}{|c|}{$\begin{array}{c}\text { Klinik uygulama } \\
\text { öncesi }\end{array}$} & \multicolumn{2}{|c|}{$\begin{array}{c}\text { Klinik uygulama } \\
\text { sonrası }\end{array}$} & \multirow[t]{2}{*}{ Analiz } \\
\hline Anksiyete düzeyi & Sayı & $\%$ & Sayı & $\%$ & \\
\hline Hafif (8-15 puan) & 33 & 55 & 19 & 31.7 & \multirow{4}{*}{$\mathrm{p}=0.061$} \\
\hline Orta ( $16-25$ puan) & 14 & 23.3 & 22 & 36.7 & \\
\hline Şiddetli (26-63 puan) & 11 & 18.3 & 19 & 31.7 & \\
\hline Toplam & 58 & 96.7 & 60 & 100 & \\
\hline
\end{tabular}

*Aynı bireylerde farklı iki zamanda tekrarlanan ölçümlerden elde edilen 'hafif-orta-şiddetli' şeklinde üç kategorili farkı test etmek için, bağımlı iki örneklem testi olan Mc Nemar Bowker Testi kullanılmıştır.

Tablo 4'de araştırmaya katılan öğrencilerin Beck Anksiyete Ölçeği'nden puanları klinik uygulama öncesi ve klinik uygulama sonrası olacak şekilde karşılaştırılmıştır. Ölçek puanlarına göre anksiyete düzeyleri klinik uygulama önce ve sonrası olarak karşılaştırıldığında aralarında istatistiksel olarak anlamlı fark bulunmamıştır ( $p>0.05)$. 
Tablo 5. Katılımcıların bazı değişkenlere göre klinik uygulama öncesi ve klinik uygulama sonrası anksiyete düzeylerinin karşılaştırılması

\begin{tabular}{|c|c|c|c|c|c|c|c|c|c|c|c|c|c|c|}
\hline \multirow{3}{*}{\multicolumn{2}{|c|}{ Değişken }} & \multicolumn{6}{|c|}{ Klinik uygulama Öncesi } & \multicolumn{6}{|c|}{ Klinik uygulama Sonrası } & \multirow{3}{*}{$\begin{array}{c}\text { Analiz* } \\
\text { (p değeri) }\end{array}$} \\
\hline & & \multicolumn{2}{|c|}{ Hafif } & \multicolumn{2}{|c|}{ Orta } & \multicolumn{2}{|c|}{ Şiddetli } & \multicolumn{2}{|c|}{ Hafif } & \multicolumn{2}{|c|}{ Orta } & \multicolumn{2}{|c|}{ Şiddetli } & \\
\hline & & Sayı & $\%$ & Sayı & $\%$ & Sayi & $\%$ & Sayı & $\%$ & Sayl & $\%$ & Sayı & $\%$ & \\
\hline \multirow{2}{*}{ Cinsiyet } & Kadın & 16 & 27.6 & 13 & 22.4 & 6 & 10.3 & 10 & 16.7 & 15 & 25.0 & 11 & 18.3 & 0.168 \\
\hline & Erkek & 17 & 29.3 & 1 & 1.7 & 5 & 8.6 & 9 & 15.0 & 7 & 11.7 & 8 & 13.3 & 0.046 \\
\hline \multirow[t]{2}{*}{ Yaş } & 20 ve alt1 & 28 & 48.3 & 14 & 24.1 & 10 & 17.2 & 18 & 30.0 & 20 & 33.3 & 16 & 26.7 & 0.182 \\
\hline & 21 ve üstü & 5 & 8.6 & 0 & 0 & 1 & 1.7 & 1 & 1.7 & 2 & 3.3 & 3 & 5.0 & $* *$ \\
\hline \multirow{3}{*}{$\begin{array}{c}\text { Gelir } \\
\text { durumu }\end{array}$} & $\begin{array}{l}\text { Gelirim } \\
\text { fazla }\end{array}$ & 3 & 5.2 & 1 & 1.7 & 2 & 3.4 & 3 & 5.0 & 0 & 0 & 3 & 5.0 & $* *$ \\
\hline & $\begin{array}{c}\text { Gelir } \\
\text { giderim } \\
\text { esit }\end{array}$ & 13 & 22.4 & 5 & 8.6 & 2 & 3.4 & 6 & 10.0 & 9 & 15.0 & 6 & 10.7 & 0.038 \\
\hline & $\begin{array}{l}\text { Giderim } \\
\text { fazla }\end{array}$ & 17 & 29.3 & 8 & 13.8 & 7 & 12.1 & 10 & 16.7 & 13 & 21.7 & 10 & 16.7 & 0.217 \\
\hline \multirow{2}{*}{$\begin{array}{l}\text { Çalışma } \\
\text { durumu }\end{array}$} & Evet & 2 & 3.4 & 0 & 0 & 0 & 0 & 0 & 0 & 1 & 1.7 & 1 & 1.7 & $* *$ \\
\hline & Hayır & 31 & 53.4 & 14 & 24.1 & 11 & 19.0 & 19 & 31.7 & 21 & 35.0 & 18 & 30.0 & 0.108 \\
\hline \multirow{2}{*}{$\begin{array}{c}\text { Sigara } \\
\text { kullanma } \\
\text { durumu }\end{array}$} & Evet & 6 & 10.3 & 0 & 0 & 2 & 3.4 & 6 & 10.0 & 1 & 1.7 & 2 & 3.3 & $* *$ \\
\hline & Hayır & 27 & 46.6 & 14 & 24.1 & 9 & 15.5 & 13 & 21.7 & 21 & 35.0 & 17 & 28.3 & 0.062 \\
\hline \multirow{2}{*}{$\begin{array}{l}\text { Hemşirelik } \\
\text { Bölümünü } \\
\text { isteyerek } \\
\text { seçme } \\
\text { durumu }\end{array}$} & Evet & 23 & 39.7 & 9 & 15.5 & 6 & 10.3 & 10 & 16.7 & 17 & 28.3 & 16 & 21.7 & 0.05 \\
\hline & Hayır & 10 & 17.2 & 5 & 8.6 & 5 & 8.6 & 9 & 15.0 & 5 & 8.3 & 6 & 10.0 & 0.881 \\
\hline
\end{tabular}

*Aynı bireylerde farklı iki zamanda tekrarlanan ölçümlerden elde edilen 'hafif-orta-şiddetli' şeklinde üç kategorili farkı test etmek için, bağımlı iki örneklem testi olan Mc Nemar Bowker Testi kullanılmıştır.

**Gözlere düşen kişi sayısı sıfır olduğu için analiz yapılamamıştır. 
Tablo 5'de, araştırmaya katılan öğrencilerin Beck Anksiyete Ölçeği puanlarına göre anksiyete düzeyleri hafif, orta ve şiddetli olarak karşılaştırıldığında; klinik uygulama öncesi ve klinik uygulama sonrası cinsiyet, gelir durumu ve bölümü isteyerek seçme durumları aralarındaki fark istatiksel olarak anlamlı bulunmuştur $(\mathrm{p}<0,05)$. Erkek öğrencilerin klinik uygulama sonrası anksiyete düzeyleri klinik uygulama öncesi anksiyete düzeylerine göre artmış olup aralarındaki fark istatistiksel olarak anlamlıdır $(\mathrm{p}<0,05)$. Ayrıca, hemşirelik bölümünü isteyerek seçtiğini ifade eden öğrencilerin klinik uygulama sonrası anksiyete düzeyleri klinik uygulama öncesine göre anlamlı şekilde artış göstermiştir $(\mathrm{p}=0,05)$.

\section{TARTIŞMA}

Çalışmamızda öğrencilerin çoğu (\%66.7) hemşirelik bölümünü isteyerek seçtiğini ifade etmiştir (Tablo 1). Uyku düzeyi, öğrencilerin hem fiziksel ve ruhsal sağlıklarını hem de akademik başarılarını etkiler. Kalitesiz uyku, sağlı̆̆ olumsuz etkilerken zihinsel ve duygusal fonksiyonlarda da gerilemeye sebep olur (17). Klinik uygulama öncesi 14 öğrencinin uyku kalitesi iyi iken, klinik uygulama sonrası sadece 7 öğrencinin uyku kalitesi iyi olarak bulunmuştur (Tablo 2). Üniversite öğrencilerinde uyku kalitesini inceleyen bir çalışmada ise PUKİ puan ortalaması $6,9 \pm 2,4$ olarak bildirilmiştir (18). Başka bir çalışmada ise sağlık personellerinde PUKİ puan ortalaması 6.96 \pm 3.19 olarak bildirilmiştir (19). Başka bir çalışmada, vardiya sistemiyle çalışan hemşire, doktorların ve uzun süre boyunca uçuş yapan personelin yorgunluk puanlarına bakıldığında en yüksek puanı hemşirelerin aldığg görülmüştür (20). Ayrıca çalışmamızda öğrencilerin klinik uygulama öncesi \%76.7' sinin PUKİ puanı 5 ve altında, klinik uygulama sonrası \%88.3'ünün PUKİ puanı 5 ve altında bulunmuştur. Bu durum öğrencilerin çoğunun uyku kalitesinin kötü olduğunu göstermektedir. Aynı zamanda klinik uygulama sonrası öğrencilerin uyku kalitesi klinik uygulama öncesine göre düşüş göstermiştir. $\mathrm{Bu}$ durum klinik uygulamaya çıkma durumunun öğrencilerin uyku kalitesini olumsuz yönde etkilediğini ortaya koymaktadır.

Uyku kalitesi iyi ve kötü olanların yaş, cinsiyet, gelir durumu, çalışma, sigara kullanma ve bölümü isteyerek seçme durumlarına göre PUKİ değerleri klinik uygulama öncesi ve sonrası olarak karşılaştırıldığında aralarında istatistiksel açıdan anlamlı fark bulunmamıştır ( $\mathrm{p}>0.05)$. Bununla beraber tüm kişisel özelliklerde, klinik uygulama sonrası PUKİ puan ortalamaları klinik uygulama öncesi PUKİ puan ortalamalarına göre daha yüksektir. Bu sonuç literatürle uyumludur $(21,22)$. 
Araştırmaya katılan öğrencilerin Beck Anksiyete Ölçeği puanlarına göre anksiyete düzeyleri klinik uygulama öncesi ve sonrası olarak karşılaştırıldığında aralarında istatistiksel olarak anlamlı fark bulunmamıştır ( $\mathrm{p}>0.05)$. Bununla beraber, araştırmaya katılan öğrencilerin Beck Anksiyete Ölçeği puanlarına göre anksiyete düzeyleri hafif, orta ve şiddetli olarak karşılaştırıldığında; klinik uygulama öncesi ve klinik uygulama sonrası cinsiyet, gelir durumu ve bölümü isteyerek seçme durumları aralarındaki fark istatiksel olarak anlamlı bulunmuştur $(\mathrm{p}<0,05)$. Erkek öğrencilerin klinik uygulama sonrası anksiyete düzeyleri klinik uygulama öncesi anksiyete düzeylerine göre daha yüksek bulunmuştur $(p<0,05)$. Başka bir çalışmada öğrencilerin anksiyete görülme sıklığ $\%$ 28,5 bulunmuştur (23). Üniversite öğrencileri ile yapılan başka bir çalışmada ise anksiyete sıklığı \% 30,6 olduğu bildirilmiştir (24). Çalışmamızda literatüre benzer şekilde anksiyete ölçek puanları yüksek bulunmuştur. Aynı zamanda klinik uygulama sonrası öğrencilerin Beck Anksiyete Ölçeğinden aldıkları puanlar klinik uygulama öncesine göre artış göstermiştir. Bu durum klinik uygulamanın öğrencilerde bir stres kaynağı olabileceğini ve anksiyete düzeylerini artırdığını göstermektedir. Ayrıca öğrencilerin klinik uygulama sonrası uyku kalitelerinin düşmesi de anksiyete düzeylerini etkilemiş olabilir.

\section{Sonuç ve Öneriler}

Hemşirelik birinci sınıfta eğitim görmekte olan öğrencilerin klinik uygulama öncesi ve sonrası anksiyete ve uyku kalitesi düzeylerini ve bunlara etki eden faktörleri belirlemek amaciyla yapılan çalışmamızda, öncelikle öğrencilerin çoğunun uyku kalitesinin kötü olduğu ve bu oranın klinik uygulama sonrası daha da arttığı görülmüştür. Hemşirelik gibi mesleklerde verilen eğitim programlarının zor ve yoğun olması nedeniyle, öğrencilerin uyku kalitelerinin bozulması olasıdır (25). Bu yüzden, uyku kaliteleri kötü olan öğrencilerin fiziksel, mental ve duygusal açıdan olumsuz etkilenmeleri kaçınılmazdır. Ayrıca, öğrencilerde uyku kalitesinin bozukluğunun akademik başarıyı da olumsuz etkilediği de bilinmektedir (26). İnsan sağlığıyla bire bir ilişkili olan meslek mensuplarının fiziksel ve mental olarak tam anlamıyla bir iyilik durumunda olmaları ve bu durumu devam ettirmeleri çok önemlidir. Bunun için sağlığın korunmasında en önemli faktörler arasında yer alan kaliteli uykunun sürdürülmesi gerekmektedir.

Çalışmamızda öğrencilerin klinik uygulama öncesi ve klinik uygulama sonrası Beck Anksiyete Ölçeği puanlarına göre orta düzeyde anksiyete belirtileri gösterdikleri görülmüştür. Bu durum klinik uygulama öncesinde de, anksiyete yaşayan öğrencilerin klinik uygulama sonrasında da 
anksiyete yaşadıklarını hatta klinik uygulamanın anksiyete düzeylerini artırdığını göstermektedir. Ayrıca PUKİ puanlarına göre uyku kalitesi klinik uygulama sonrası daha da kötüye giden öğrencilerin aynı şekilde anksiyetelerinin de arttığı görülmüştür. Bu açıdan, öğrencilerin uyku kalitesinin anksiyete düzeyini etkilediği görülmektedir.

Hemşirelik öğrencilerinin klinik uygulama öncesi ve sonrasında, uyku kalitesi ile anksiyete düzeyini ortaya koyan çalışmaların planlanması önerilmektedir. Ayrıca öğrencilerin duygusal sağlık durumlarıyla ilgili farkındalık oluşturmak için düzenli aralıklarla eğitimler verilmelidir. $\mathrm{Bu}$ taramalar sonucu belirlenen riskli öğrenci gruplarına sosyal ve emosyonel destek verilmelidir.

\section{KAYNAKLAR}

1. Beesdo KS, Knappe S, Pine DS., Anxiety and anxiety disorders in children and adolescents: developmental issues and implications for DSM-V. Psychiatr Clin North Am. 2009; 32(3): 483-524.

2. Castellanos D, Hunter T. Anxiety disorders in children and adolescents. South Med J. 1999; 92(10): 94654.

3. İtil O, Köktürk O, Ardıç S, Çuhadaroğlu Ç, Fırat H. (Ed.) Uykuda Solunum Bozuklukları. Ankara: Türk Toraks Deneği Kitapları; 2015.

4. Ağargün MY, Kara Y, Anlar Ö. Pittsburgh Uyku kalitesi indeksi’nin geçerliği ve güvenirliği. Türk Psikiyatri Dergisi. 1996;7(2):107-115.

5. Ulusoy MF. Nitelikli hemşirelik eğitimi için nitelikli uygulama ortamı. Hemşirelik-Ebelik Eğitim ve Uygulamalarında Kalite Sempozyumu; 1998; Kayseri.

6. Audet MC. Caring in Nursing Education: Reducing Anxiety in The Clinical Setting. Nursing Connections 1995; 8(3): 21-28.

7. Chesser-Smyth PA. The lived experience of general student nurses on their first clinical placement: a phenomenological study. Nurse Education in Practice 2005; 5: 320-327.

8. Atalay M, Tel H, Altun E, Tel H. Hemşirelik birinci sınıf öğrencilerinin klinik uygulamada yaşadıkları güçlükler ve yardım beklentileri. Hacettepe Üniversitesi Hemşirelik Yüksekokulu Dergisi 1994; 1: 19-2.

9. Yetkin A, Özer H. Atatürk Üniversitesi Hemşirelik Yüksekokulu birinci sınıf öğrencilerinin klinik uygulamaya ilişkin kaygı düzeylerinin incelenmesi. 6. Anadolu Psikiyatri Kongresi Bilimsel Çalışmalar Kitabi; 1997. 215-220.

10. Yeniçeri N, Mevsim V, Özçakar N, Özan S, Güldal D, Başak O. Tıp eğitimi son sınıf öğrencilerinin gelecek meslek yaşamları ile ilgili yaşadıkları anksiyete ile sürekli anksiyetelerinin karşılaştırılması. DEÜ Tip Fakültesi Dergisi 2007; 21 (1): 19-24.

11. Jones MC, Johnston DW. Distress Stress and Coping in First Year Student Nurses. Journal of Advanced Nursing 1997; 26 (3): 470-474.

12. Şirin A, Kavak O, Ertem G. Doğumhane stajına çıkan öğrencilerin durumluk-sürekli kaygı düzeylerinin belirlenmesi. Cumhuriyet Üniversitesi Hemşirelik Yüksekokulu Dergisi 2003;7(1): 27-32 
13. Ağargün MY, Kara H, Anlar O. Gece vardiyasında çalışan hemşirelerde öznel uyku kalitesi. Van Tıp Dergisi 1996;3(1):16-18.

14. West SD, Nicall DC, Stradling JR. Prevalence of obstructive sleep apnoea in men with type 2 diabetes. Thorax 2006; 61: 945- 950.

15. Fiorentini A, Valente R, Perciaccante A et al. Sleep's quality disorders in patients with hypertension and type 2 diabetes mellitus. International Journal of Cardiology 2007; 8(2): 8114.

16. Ulusoy M, Sahin NH, Erkmen H. Turkish version of the beck anxiety inventory: psychometricproperties. J CognPsychother 1998; 12: 163-72

17. Orzech KM, Salafsky DB, Hamilton LA. The state of sleep among college students at a large public university. Journal of American College Health. 2011; 59 (7): 612-619.

18. Saygılı S, Akıncı AÇ, Arıkan H, Dereli E. Üniversite öğrencilerinde uyku kalitesi ve yorgunluk. Electronic Journal of Vocational Colleges. 2011; 1(1):88-99.

19. Karakoç B. Uyku kalitesi üzerine bir çalışma: Özel dal hastanesi sağlık çalışanları örneği. Yayınlanmamış yüksek Lisans Tezi. İstanbul: T.C Marmara Üniversitesi Sağlık Bilimleri Enstitüsü; 2009.

20. Çalıyurt O. Sirkadiyen uyku uyanıklık düzenini etkileyen iş ve çalışma gruplarında uyku kalitesinin değerlendirilmesi. Yayınlanmamış Uzmanlık Tezi. Edirne: T.C. Trakya Üniversitesi Tıp Fakültesi Psikiyatri Anabilim Dalı; 1998.

21. Yılmaz E, Kutlu AK, Çeçen D. Cerrahi kliniklerinde yatan hastaların uyku durumlarını etkileyen faktörler. Yeni Tıp Dergisi 2008;25:149-156.

22. Yüksel DS. Hastanede Yatan Hastaların Uyku Kalitesi ve Uyku Durumlarını Etkileyen Faktörlerin Değerlendirilmesi. Yüksek lisans tezi. İstanbul: İstanbul Bilim Üniversitesi Sağlı Bilimleri Enstitüsü;2014.

23. Hamaideh SH. Alexithymia among jordanian university students: its prevalence and correlates with depression, anxiety, stress, and demographics. Perspect Psychiatr Care 2017;Jul 20. doi: $10.1111 /$ ppc. 1223

24. İbrahim AK, Kelly SJ, Adams CE. A systematic review of studies of depression prevalence in university students. J. Psychiatr. Res. 2013; 47(3): 391-400.

25. Mayda AS, Kasap H, Yıldırım C, Yılmaz M, Derdiyok Ç, Ertan D, ve ark. 4-5-6. sınıf tıp fakültesi öğrencilerinde uyku bozukluğu sıklığı. Düzce Üniversitesi Sağlık Bilimleri Enstitüsü Dergisi 2012; 2 (2): 8-11.

26. Curcio G, Ferrara M, Gennaro L. Sleep Loss, Learning capacity and academic performance. Sleep Med Rev. 2015;10: 323-337. 